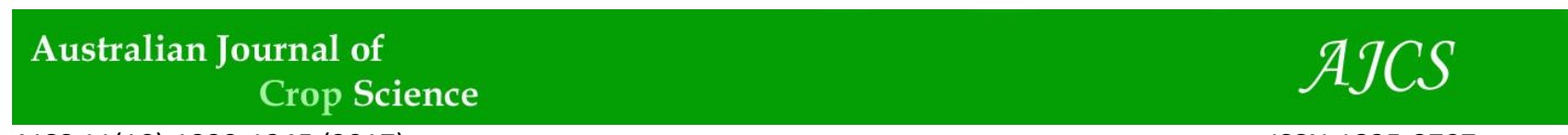

AJCS 11(10):1339-1345 (2017)

ISSN:1835-2707

doi: 10.21475/ajcs.17.11.10.pne645

\title{
Application of different cover crops and mineral fertilizer doses for no-till cultivation of broccoli,
} cauliflower and cabbage

\author{
José Luiz Rodrigues Torres ${ }^{1 *}$, Fernando Rodrigues da Cunha Gomes ${ }^{2}$, Antônio Carlos Barreto ${ }^{3}$, \\ Amanda Yamada Tamburús ${ }^{2}$, Dinamar Márcia da Silva Vieira ${ }^{4}$, Zigomar Menezes de Souza ${ }^{5}$, \\ José Carlos Mazetto Júnior ${ }^{4}$
}

${ }^{1} \mathrm{PhD}$ in Agronomy / Plant Production, Federal Institute of Mining Triangle (IFTM) - Uberaba Campus, MG, Brazil, Rua João Batista Ribeiro, 4000, Uberaba-MG, Brazil. Zip code: 38064-790

${ }^{2}$ Agronomy, IFTM Campus Uberaba IFTM Campus Uberaba, Rua João Batista Ribeiro, 4000. Uberaba-MG, Brazil. Zip code: $38064-790$.

${ }^{3}$ Irrigation, IFTM Uberaba Campus, MG, Brazil. Rua João Batista Ribeiro, 4000. Uberaba-MG, Brazil. Zip code: 38064-790.

${ }^{4}$ Graduate Program in Agronomy, Institute of Agricultural Sciences at the Federal University of Uberlândia. Av. Amazonas s/n', Umuarama. Uberlândia-MG, Brazil. Zip code: 38400-902.

${ }^{5}$ State University of Campinas, School of Agricultural Engineering (Feagri, Department of Water and Soil, Avenida Cândido Rondon, 501, Cidade Universitária Zeferino Vaz, Barão Geraldo, CEP 13083-875 Campinas, SP, Brasil

*Corresponding author: jlrtorres@iftm.edu.br

\begin{abstract}
No-till practices have not been widely adopted by vegetable producers due to the necessity of seedbed preparation to incorporate organic fertilizers and plant residues of the preceding crops. This study evaluated biomass yield and residue decomposition of different cover crops, and their influence on agronomic performance of Brassica crops cultivated under no-till system. The experiment was laid out in randomized complete blocks with 4 × 3 factorial treatment combinations of four cover crops: Sunn hemp (SH), Signal grass (SG), Pearl millet (PM), and SH + PM mixture, and three doses of mineral fertilizer - 0,50 , and $100 \%$ of the recommended fertilizer doses for broccoli. The same design and treatments were used for cauliflower and then for cabbage, separately.. The experiment was carried out with 4 repetitions on parcels of $20 \mathrm{~m}^{2}$. No beds were raised, for the planting of seedlings was done in pits. The following agronomic traits were evaluated: Dry biomass (DB) and decomposition of cover crop residues (DR), and the number of leaves (NL), height $(\mathrm{H})$, fresh head weight (FHW) and dry head weight (DHW), and yield (Y) of Brassica crops. The highest DB occurred in treatments with SH (Give value). SG presented the highest DR constant and the shortest half-life of residues in this study.; Broccoli presented better agronomic performance when cultivated on residues containing SH.; Fertilizer doses influenced broccoli and cabbage productivity, which were the highest for the treatment with $100 \%$ dose of mineral fertilizer.
\end{abstract}

Key words: cover crops, decomposition, nutrient cycling.

Abbreviations: NTS_No-till system, DB_Dry biomass, DR_Decomposition of cover crop residues, SG_Signal grass, SH_Sunn hemp, PM_Pearl millet, SH + PM_Sunn hemp + Pearl millet, N_Nitrogen, P_Phosphorus, K_Potassium, B_Borron, C/N_Carbon/nitrogen ratio, $\mathrm{t} \mathrm{ha}^{-1}{ }_{\text {T }}$ Tons per hectare, $\mathrm{L} \mathrm{h}^{-1}$ _Liters per hectare, NL_Number of leaves, H_Height, FHW_Fresh head weight, DHW_Dry head weight, $\bar{Y}_{-}$Y Yield, T12/2 life_Residue half-life.

Introduction

The lack of soil revolving and the presence of crop rotation and plant residues on soil surface are the basic premises of the no-till system (NTS). This system helps maintain and improve soil quality because the roots and residues left by plants can supply considerable amounts of nutrients to subsequent crops by liberating them in the superficial layer after decomposition, which could otherwise be lost in the subsurface layers of the soil (Torres et al., 2016).

Some studies show that signal grass, sunn hemp and pearl millet are the best adapted cover crops to the edaphoclimatic conditions in the Cerrado because they produce high amount of biomass, both in the dry and rainy season (Crusciol and Soratto, 2009; Chioderoli et al., 2012; Torres et al., 2015). Other studies show that these crops provide the best nutrient cycling in the Cerrado when cultivated before or after no-till

corn, soybeans, beans, rice and other crops, and that the highest amounts of nutrients are released within 42 days after terminating these cover crops (Torres et al., 2008; Fabian, 2009; Assis et al., 2013). Regarding the cultivation of most vegetables, NTS is still little used due to the necessity of seedbed preparation, and cover crops are mostly used as green fertilizers in organic production (Santos et al., 2016) where their residues are manually or mechanically incorporated into the soil (Oliveira et al., 2006). Brassicas are among the most consumed vegetables in Brazil (Carvalho et al., 2013). They have high socio-economic importance in some states, since they can be produced during the whole year, grow fast, have high nutritional and commercial value (Kano et al., 2010), and their seedlings can be planted in pits. However, these plants require large amounts of nutrients in 
relatively short periods of time, which are usually supplied through mineral fertilizers and supplemented by manure or organic compounds (Oliveira et al., 2005).

One of the alternatives to reduce the use of mineral fertilizers in the production of vegetables is the cultivation of cover crops before planting the seedlings into pits, without the preparation of seedbed (Torres et al., 2015, Perin et al., 2015). The decomposition of the residues deposited on the soil can provide considerable amounts of nutrients (Leite et al., 2010) for 45 days after planting, when most of the cultivated vegetables demand high amounts of nutrients for their development (Brito and Santos, 2010).

Some studies have demonstrated that the cultivation of different coverings of the soil before the commercial crop, associated to organic or mineral fertilization, bring beneficial effects to successor crops. With cabbage, Fontanétti et al. (2006) used $12.7 \mathrm{t} \mathrm{ha}^{-1}$ dry biomass of crotalaria juncea, 8.50 $\mathrm{t} \mathrm{ha}^{-1}$ of black mucuna, $7.51 \mathrm{t} \mathrm{ha}^{-1}$ of pork and $5.2 \mathrm{t} \mathrm{ha}^{-1}$ of spontaneous vegetation, associated to $100 \mathrm{~kg} \mathrm{ha}^{-1} \mathrm{P}_{2} \mathrm{O}_{5}, 100$ $\mathrm{kg} \mathrm{ha}^{-1}$ of $\mathrm{K}_{2} \mathrm{O}$ and $150 \mathrm{~kg} \mathrm{ha}^{-1}$ of $\mathrm{N}$, split at 30,45 and 65 days after planting, plus $1 \mathrm{~g}$ of boric acid per well resulted in the production of heads of broccoli with 1.4, 1.2, 1.2 and 2.0 $\mathrm{kg}$, respectively. Vargas et al. (2011) using 50\% of the recommended dose of mineral fertilization added to dry biomass of sunflower and pigs resulted in cabbage production, similar to that obtained with $100 \%$ mineral fertilization, yielding between 1.9 and $2.3 \mathrm{~kg}_{\text {plant }}{ }^{-1}$, which corresponds to productivity of 47.0 to $58.0 \mathrm{t} \mathrm{ha}^{-1}$.

In the Cerrado, no-till management of vegetables has been adopted mostly in the production of tomatoes, while research data regarding the cultivation of other vegetables especially Brassica crops are scarce (Perin et al., 2015). Therefore, studies evaluating the cultivation of these crops under NTS are justified. In this context, the objective of this study was to evaluate biomass yield and residue decomposition of different cover crops, and their influence on agronomic performance of Brassica crops under no-till system.

\section{Results and discussion}

\section{Cover crops}

\section{Dry biomass production of cover crops}

The results demonstrate that on irrigated plots in 2014 dry biomass (DB) yield for the treatment with sunn hemp + pearl millet $\left(23.15 \mathrm{t} \mathrm{ha}^{-1}\right)$ was significantly higher $(\mathrm{p}<0.05)$ when compared to monocultures of sunn hemp $\left(19.20 \mathrm{t} \mathrm{ha}^{-1}\right)$, pearl millet $\left(17.23 \mathrm{t} \mathrm{ha}^{-1}\right)$ and signal grass $\left(9.86 \mathrm{t} \mathrm{ha}^{-1}\right)$.

Under the same soil and climatic conditions of the Cerrado, DB yield of cover plants on irrigated plots in this experiment was higher than under rainfed conditions (Fabian, 2009; Crusciol and Soratto, 2009; Carvalho et al., 2011; Torres et al., 2015). This fact occurred because there was no lack of water during the initial stage of crop development, Beyond the coverage of the soil provided by the plants used, that may have provided greater retention of moisture and amount of nutrients available in the soil solution, which were used by plants in its development.

High DB yield observed for the treatment with sunn hemp+pearl millet $\left(23.15 \mathrm{t} \mathrm{ha}^{-1}\right)$ was probably caused by good root and vegetative development of the plants. Poaceae are characterized by active and continuous root growth, high biomass yield capacity, high nutrient recycling and soil conservation, which positively correlates with the following soil parameters: organic matter, nutrient status, aggregation, structure, permeability and infiltration. Fabaceae, on the other hand, play a key role as nutrient suppliers since they can quickly provide nutrients to successor crops due to rapid decomposition of their residues (Assis et al., 2013).
Results obtained in this study are similar to other published results, which report that crop mixtures with sunn hemp presented higher yield of biomass. It is because this crop is a great nutrient supplier, mainly nitrogen through biological fixation (Bettiol and Sá, 2013).

\section{Residue decomposition rate of cover crops}

Analyzing the residue decomposition rate in 2014-15, we observed that 120 days after the distribution of nylon bags there were still $40.63,34.33,28.85$, and $27.47 \%$ of residues of SG, PM, SH + PM mixture, and SH left (Figure 1), respectively. The results demonstrate that where sunn hemp was present, either in monoculture or in mixture, the decomposition of the residues occurred more rapidly because the carbon/nitrogen ratio $(\mathrm{C} / \mathrm{N})$ in Fabaceae is lower than in Poaceae.

According to Giacomini et al. (2003), Fabaceae/Poaceae mixtures provide soil cover for a longer period of time and better supply of nutrients, because these consortiums produce straw with an intermediate $\mathrm{C} / \mathrm{N}$ ratio when compared to monocultures of these plants. This fact causes slower decomposition of Fabaceae residues, thus providing soil cover for longer time and higher demand for $\mathrm{N}$ by crops.

Other studies have evaluated decomposition rates of pearl millet, sunn hemp and signal grass residues under rainfed conditions. They evidenced that the highest decomposition rates always occur for Fabaceae and the lowest for Poaceae (Carvalho et al., 2011; Assis et al. 2013; Torres et al., 2008; 2015). The studies also show that decomposition rates are directly influenced by rainfall, since decomposition increases with higher precipitation and decreases to minimum values in the dry season (Leite et al., 2010; Torres et al., 2013).

\section{Decomposition constant and residue half-life}

Water influence on residue decomposition was also found in this study: their half-life was between 11 and 17 days in $2014 / 15$ (Table 1). Another important corroboration is that mixtures of cover crop species presented intermediate values when compared to monocultures. In studies conducted in 2001/02 under rainfed conditions, Torres et al. (2005) found $\mathrm{T}^{1 / 2}$ life of pearl millet residues $=90$ days, sunn hemp $=64$ days, and signal grass $=95$ days, while Fabian (2009) found $\mathrm{T}^{1 / 2}$ life of pearl millet residues $=114$ and 112 days, sunn hemp $=112$ and 120 days, and signal grass $=42$ and 37 days in 2005/06 and 2006/07, respectively.

\section{Agronomic evaluation of main crops}

\section{Broccoli (Brassica oleracea var. Italica)}

Evaluating agronomic characteristics of broccoli grown after cover crops, it was observed that fresh head weight (FHW) and yield were statistically equal $(\mathrm{p}<0.05)$ in treatments after Fabacea (SH, and SH + PM mixture), and higher than in treatments after Poaceae (SG and PM) (Table 2). This can be explained by higher DB yield of these crops and probably greater nutrient cycling, mainly $\mathrm{N}$, due to high biological fixation by sunn hemp. Fontanétti et al. (2006) highlight that nutrient uptake after the mineralization of organic matter depends on the synchrony between the period of nutrient release from the residues through decomposition and the period of high nutritional demand by the crop, but that such synchrony should occur naturally.

According to Souza et al. (2011), the maintenance of residues of cover plants on the soil is highly recommended because it improves crop performance and increases soil moisture retention. 
Table 1. Decomposition constant $(\mathrm{k})$ and half-life $\left(\mathrm{T}^{1 / 2}\right.$ life) of residue material (RM) of cover crops on irrigated plots, Uberaba, 2014.

\begin{tabular}{lccc}
\hline Cover crops & \multicolumn{2}{c}{$\mathrm{RM}$} & $\mathrm{r}^{2}$ \\
\cline { 2 - 4 } Mg & $\mathrm{k}$ & $\mathrm{T}^{1 / 2}$ life & \\
\cline { 2 - 4 } SG & $\mathrm{g} \mathrm{g}^{-1}$ & Days & $0.97^{*}$ \\
PM & 0.0647 & 11 & 0.96 \\
SH & 0.0562 & 12 & 0.96 \\
SH+PM mixture & 0.0398 & 17 & 0.95
\end{tabular}

$*=$ Significant $(\mathrm{p}<0.01) ; \mathrm{r}^{2}=$ determination coefficient. SG $=$ Signal grass, SH $=$ Sunn hemp, PM = Pearl millet, and SH + PM mixture $=$ Sunn hemp + Pearl millet mixture.

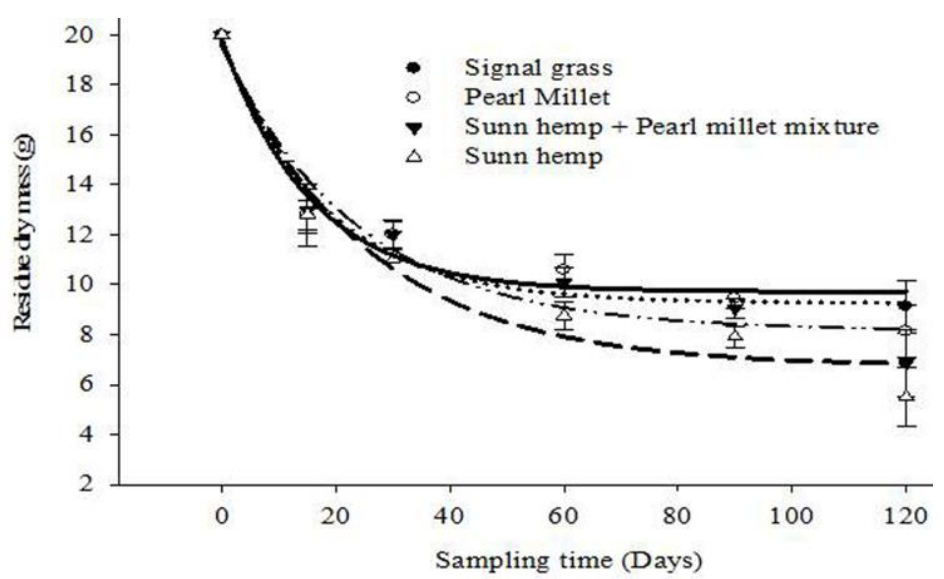

Fig 1. Residue decomposition on irrigated plots under Brassica crops in 2014.

Table 2. Agronomic traits of broccoli grown on residues of different cover crops and doses of mineral fertilizer $(0,50$, and $100 \%$ of recommended fertilization), in Uberaba-MG.

\begin{tabular}{|c|c|c|c|c|c|}
\hline \multirow[t]{2}{*}{ Cover crops } & \multicolumn{5}{|c|}{ Broccoli } \\
\hline & NL & Height & FHW & DHW & Yield \\
\hline $\mathrm{Mg}$ & -- & $\mathrm{cm}$ & $\mathrm{kg}_{\text {plant }}{ }^{-1}$ & $\mathrm{~kg}_{\text {plant }}{ }^{-1}$ & $\mathrm{t} \mathrm{ha}^{-1}$ \\
\hline \multicolumn{6}{|c|}{ Cover crops } \\
\hline SG & $31 \mathrm{a}^{\text {ns }}$ & $16.0 \mathrm{a}^{\mathrm{ns}}$ & $0.82 b^{*}$ & $0.06 \mathrm{a}^{\mathrm{ns}}$ & $20.5 b^{*}$ \\
\hline PM & $31 \mathrm{a}$ & $14.8 \mathrm{a}$ & $0.81 \mathrm{~b}$ & $0.06 \mathrm{a}$ & $21.4 \mathrm{~b}$ \\
\hline SH & $32 \mathrm{a}$ & $15.2 \mathrm{a}$ & $0.97 \mathrm{a}$ & $0.07 \mathrm{a}$ & $24.7 \mathrm{a}$ \\
\hline $\mathrm{SH}+\mathrm{PM}$ mixture & $33 \mathrm{a}$ & $16.2 \mathrm{a}$ & $1.00 \mathrm{a}$ & $0.07 \mathrm{a}$ & $24.9 \mathrm{a}$ \\
\hline \multicolumn{6}{|c|}{ Fertilizer doses } \\
\hline 0.0 & $31 \mathrm{~b}^{*}$ & $15.9 \mathrm{a}^{\mathrm{ns}}$ & $0.79 b^{*}$ & $0.05 b^{*}$ & $20.5 b^{*}$ \\
\hline 50 & $31 \mathrm{~b}$ & $15.4 \mathrm{a}$ & $0.90 \mathrm{a}$ & $0.07 \mathrm{a}$ & $22.8 \mathrm{~b}$ \\
\hline 100 & $33 a$ & $16.2 \mathrm{a}$ & $1.01 \mathrm{a}$ & $0.08 \mathrm{a}$ & $25.3 \mathrm{a}$ \\
\hline $\mathrm{CV}(\%)$ & 6.91 & 8.91 & 11.06 & 12.28 & 9.44 \\
\hline
\end{tabular}

Table 3. Agronomic traits of cauliflower grown on residues of different cover crops and doses of mineral fertilizer $(0,50$, and $100 \%$ of recommended fertilization), in Uberaba-MG.

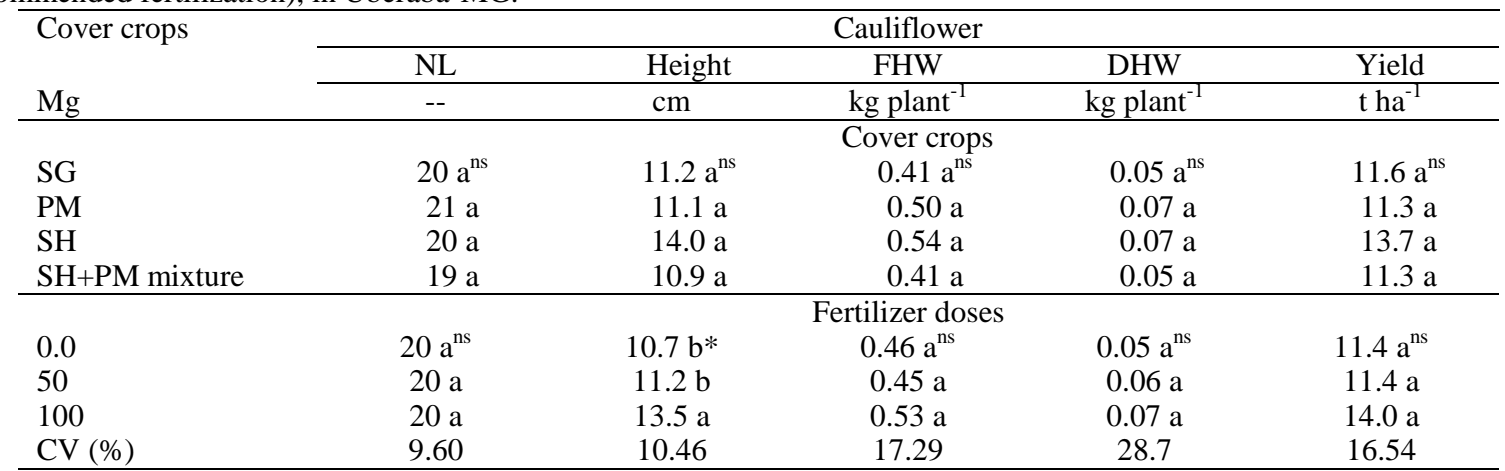

${ }^{\mathrm{ns}}=$ Not significant and $*$ = Significant. Means followed by the same letter in the column do not differ (Tukey, $\mathrm{p}<0.05$ ). NL $=$ number of leaves; FHW = fresh head weight; DHW = dry head weight, Signal grass, $\mathrm{SH}=$ Sunn hemp, PM = Pearl millet, and SH + PM mixture $=$ Sunn hemp + Pearl millet mixture. 
Table 4. Agronomic traits of cabbage grown on residues of different cover crops and doses of mineral fertilizer $(0,50$, and $100 \%$ of recommended fertilization), in Uberaba-MG.

\begin{tabular}{|c|c|c|c|c|c|}
\hline \multirow[t]{2}{*}{ Cover crops } & \multicolumn{5}{|c|}{ Cabbage } \\
\hline & NL & Height & FHW & DHW & Yield \\
\hline $\mathrm{Mg}$ & -- & $\mathrm{cm}$ & kg plant $^{-1}$ & $\mathrm{~kg}_{\text {plant }}{ }^{-1}$ & tha $^{-1}$ \\
\hline & & & Cover crops & & \\
\hline SG & $15 \mathrm{a}^{\mathrm{ns}}$ & $11.2 \mathrm{a}^{\mathrm{ns}}$ & & $0.35 \mathrm{a}^{\mathrm{ns}}$ & $43.5 \mathrm{a}^{\mathrm{ns}}$ \\
\hline PM & $14 \mathrm{a}$ & $11.1 \mathrm{a}$ & $1.33 \mathrm{a}$ & $0.33 \mathrm{a}$ & $44.3 \mathrm{a}$ \\
\hline SH & $14 \mathrm{a}$ & $14.0 \mathrm{a}$ & $1.34 \mathrm{a}$ & $0.35 \mathrm{a}$ & $45.7 \mathrm{a}$ \\
\hline $\mathrm{SH}+\mathrm{PM}$ mixture & $14 \mathrm{a}$ & $10.9 \mathrm{a}$ & $1.33 \mathrm{a}$ & $0.33 \mathrm{a}$ & $45.3 \mathrm{a}$ \\
\hline & & & Fertilizer doses & & \\
\hline 0.0 & $15 \mathrm{a}^{\mathrm{ns}}$ & $10.7 b^{*}$ & $1.18 \mathrm{c}^{*}$ & $0.25 b^{*}$ & $32.0 \mathrm{c} *$ \\
\hline 50 & $15 \mathrm{a}$ & $11.2 \mathrm{~b}$ & $1.32 \mathrm{~b}$ & $0.25 \mathrm{~b}$ & $43.4 \mathrm{~b}$ \\
\hline 100 & $14 \mathrm{a}$ & $13.5 \mathrm{a}$ & $1.53 \mathrm{a}$ & $0.52 \mathrm{a}$ & $58.8 \mathrm{a}$ \\
\hline CV $(\%)$ & 5.99 & 10.46 & 5.86 & 14.76 & 7.70 \\
\hline
\end{tabular}

Treatments with fertilizer doses of 50 and $100 \%$ presented statistically higher number of leaves (NL), fresh head weight (FHW), and dry head weight (DHW) when compared to the treatment with $0 \%$ of fertilizer dose. The yield was significantly higher when $100 \%$ of the recommended mineral fertilizer dose was used; however, no significant correlation with cover crops was found.

In general, the residues of cover crops positively influenced agronomic traits of broccoli, such as yield which was higher in treatments with Fabaceae, either in monoculture or in mixture. However, the supply of nutrients from the residues of cover crops alone is not enough to guarantee a good yield of broccoli because treatments with 0 and $50 \%$ of fertilizer presented lower yields when compared to the dose of $100 \%$. Nevertheless, they were very close, which serves as a motivation to continue the studies and test other cover crops for the cultivation of broccoli.

In a study with residues of different cover crops, Diniz et al. (2007) observed that the application of $8.6 \mathrm{t} \mathrm{ha}^{-1}$ of dry biomass of gray mucuna and $12.0 \mathrm{t} \mathrm{ha}^{-1}$ of organic compost increased mineral $\mathrm{N}$ content in the soil, which consequently led to higher yield of broccoli.

\section{Cauliflower (Brassica oleraceae var. botrytis L.)}

No significant differences of agronomic traits of cauliflower were observed for any of the cover crops or mineral fertilizer doses (Table 3), with one exception plant, height which was higher in the treatment with $100 \%$ of mineral fertilizer. Also, there was no interaction between cover crops and fertilizer doses. These results were influenced by some problems during this research, mainly by the erroneous choice of the cultivated variety, which is not recommended for the season of this study. On several plots the formation of cauliflower heads occurred irregularly, which affected the evaluations and the results. Therefore, the studies with this crop are being repeated. Still, the yield of cauliflower was higher when compared to results found by Torres et al. (2015). However, FHW and yield obtained in this study for all treatments were lower than $1.5 \mathrm{~kg}$ of FHW and yield of $30.7 \mathrm{t} \mathrm{ha}^{-1}$ reported by Morais Junior et al. (2012) for Sharon cultivar.

\section{Cabbage (Brassica oleracea var. capitata)}

Cabbage parameters were not significantly influenced by the cover crops (Table 4). However, the same did not occur with the evaluated doses because height, FHW, DHW and yield were higher when the crop was cultivated using the $100 \%$ dose of mineral fertilizer (Table 4). The FHW observed in this study for the $50 \%$ dose was higher than $1.3 \mathrm{~kg}$ reported by Oliveira et al. (2005), and lower than $1.4 \mathrm{~kg}$ reported by Fontanétti et al. (2006) and $2.3 \mathrm{~kg}$ reported by Vargas et al. (2011), who grew cabbage on sunn hemp straw. Yet, FHW remained within the standard range required by the Brazilian consumer market, which varies between 1.0 and $1.5 \mathrm{~kg}$ (Lêdo et al., 2000). The highest nutrient uptake and growth of cabbage occurs between 60 and 70 days after transplanting (Fontanétti et al., 2006). For broccoli it begins 40 days after transplanting, and for cauliflower 54-69 days after transplanting (Castoldi et al., 2009). The uptake of nutrients released from the residues of cover crops does not appear to have occurred, because the lack of interaction between the cover crop and fertilizer doses shows that there was no synchrony between the period of high nutrient release, which takes place for up to 42 days under rainfed conditions (Torres et al., 2008; Fabian, 2009; Assis et al., 2013), and the period of high nutrient uptake by these crops. This lack of synchrony also occurs because the decomposition of residues is accelerated under irrigated conditions as evidenced in this study, which is also likely to cause faster nutrient release when compared to studies conducted under rainfed conditions. Sunn hemp (DB $=12.7 \mathrm{t}$ $\left.\mathrm{ha}^{-1}\right)$, black mucuna $\left(\mathrm{DB}=8.50 \mathrm{t} \mathrm{ha}^{-1}\right)$, jack bean $(\mathrm{DB}=$ $\left.7.51 \mathrm{t} \mathrm{ha}^{-1}\right)$, and voluntary vegetation (fallow) $(\mathrm{DB}=5.2 \mathrm{t}$ $\mathrm{ha}^{-1}$ ) preceding the cultivation of cabbage produced cabbage heads with $1.4,1.2,1.2$, and $2.0 \mathrm{~kg}$, respectively (Fontanétti et al., 2006). Vargas et al. (2011), using dry biomass of sunn hemp and jack bean and 50\% of the recommended dose of mineral fertilizer, obtained cabbage yield between 1.9 and $2.3 \mathrm{~kg}$ per plant $\left(47.0-58.0 \mathrm{t} \mathrm{ha}^{-1}\right)$, which was similar to the treatment with $100 \%$ dose of mineral fertilizer. However, Santos et al. (2016) observed that $9 \mathrm{t} \mathrm{ha}^{-1}$ of mulch did not provide significant direct effect on yield and other components of cabbage production. Yet, it significantly influenced soil moisture over time, which was always above the permanent wilting point and close to the field capacity, which allowed for the best development conditions of the crop during 87 days of cultivation. This fact was also evidenced by Montenegro et al. (2013), who highlight the importance of mulching to maintain soil moisture and control soil losses.

\section{Materials and methods}

\section{Description of the experimental site}

\section{Experimental site}

This study was carried out from February 2014 to January 2016 on a site $\left(19^{\circ} 39^{\prime} 19^{\prime \prime} \mathrm{S}\right.$ and $47^{\circ} 57^{\prime} 27^{\prime}$ 'W) that belongs to the Instituto Federal do Triângulo Mineiro, Campus 
Uberaba, MG, located at an altitude of about $800 \mathrm{~m}$.

\section{Soil type}

Soil on the experimental site was classified as Dystrophic Red Latosol (Embrapa, 2013) with medium texture. The arable layer $(0-20 \mathrm{~cm})$ contained $200 \mathrm{~g} \mathrm{~kg}^{-1}$ clay, $720 \mathrm{~g} \mathrm{~kg}^{-1}$ sand, and $80 \mathrm{~g} \mathrm{~kg}^{-1}$ slit, and presented the following chemical characteristics: $\mathrm{pH} \mathrm{H} \mathrm{H}_{2} \mathrm{O} 5.9,14.7 \mathrm{mg} \mathrm{dm}^{-3} \mathrm{P}$ (Mehlich), 112 $\mathrm{mg} \mathrm{dm}^{-3} \mathrm{~K}^{+}, 1.1 \mathrm{cmol}_{\mathrm{c}} \mathrm{dm}^{-3} \mathrm{Ca}^{2+}, 0.4 \mathrm{cmol}_{\mathrm{c}} \mathrm{dm}^{-3} \mathrm{Mg}^{2+}, 1.7$ $\mathrm{cmol}_{\mathrm{c}} \mathrm{dm}^{-3} \mathrm{H}+\mathrm{Al}$, and $6 \mathrm{~g} \mathrm{~kg}^{-1}$ organic carbon.

\section{Local climate}

According to Köppen classification, the climate in the region was classified as Aw-tropical with hot and rainy summer and cold and dry winter. Annual average rainfall, temperature, and relative air humidity in the region were $1.600 \mathrm{~mm}, 22.6^{\circ} \mathrm{C}$, and $68 \%$, respectively (Uberaba em dados, 2009).

\section{Plant material and experimental design}

The experiment was laid out in randomized complete blocks with $4 \times 3$ factorial treatment combinations of four cover crops: sunn hemp (SH) (Crotalaria juncea L.), signal grass (SG) (Urochloa brizantha cv. marandu), pearl millet (PM) (Pennisetum glaucum L. cv. ADR 500), and SH + PM mixture, and three doses of mineral fertilizer 0,50 , and $100 \%$ of recommended fertilizer dose for the crops. The treatments were carried out on broccoli (hybrid Avenger), with four repetitions on $20 \mathrm{~m}^{2}$ plots $(4.0 \times 5.0 \mathrm{~m})$. No beds were raised, for the planting of seedlings was done in pits.

After harvesting the broccoli, the same design was used in the same area ( $4 \times 3$ factorial) and treatments for cauliflower cultivation (cv Sharon), which after being harvested, the same procedure was repeated for cabbage (cv Astrus plus). The planting of the cover plants was done mechanically, without using any form of fertilization.

\section{Fertilization}

Fertilizer doses for Brassica crops were based on soil analysis and recommendations of the Soil Fertility Commission of the State of Minas Gerais (1999). The recommended nitrogen $(\mathrm{N})$, phosphorus $(\mathrm{P})$, and potassium (K) doses for the crops were: $150 \mathrm{~kg} \mathrm{ha}^{-1} \mathrm{~N}$ (urea), $100 \mathrm{~kg} \mathrm{ha}^{-}$ ${ }^{1} \mathrm{P}_{2} \mathrm{O}_{5}$, and $100 \mathrm{~kg} \mathrm{ha}^{-1} \mathrm{~K}_{2} \mathrm{O}$. Nitrogen and potassium doses were split-applied: at planting, 30 days after planting, and 45 days after planting. In addition, $1 \mathrm{~g}$ of boric acid $(17.5 \% \mathrm{~B})$ was applied per pit.

\section{Planting and management of cover crops}

The experimental site was first plowed and then harrowed twice. After that, the site was cropped with soybeans for two consecutive seasons, from November 2011 to March 2012, and from November 2012 to March 2013. After soybeans, the site was left fallow until sowing of the cover crops.

In March 2014 the cover crops (signal grass (SG), sunn hemp (SH), Pearl millet (PM), and SH + PM mixture) were mechanically sown with $0.45-\mathrm{m}$ row spacing and linear density of 50, 25, 50 and 50 seeds per meter, respectively. Approximately 100 days after planting, when more than 50\% of the plants reached full flowering stage, the plants were desiccated with $1440 \mathrm{~g} \mathrm{ha}^{-1}$ Glyphosate $+600 \mathrm{~g} \mathrm{ha}^{-1}$ Paraquat.

To evaluate dry biomass (DB) of cover crops, samples were collected from $2 \mathrm{~m}^{2}$ per plot, then dried at $65^{\circ} \mathrm{C}$ for 72 hours and weighed. Seven days after desiccation, the cover plants were cut with a weed trimmer close to the soil in order to cover the soil surface with plant material. The rate of residue decomposition was evaluated for 120 days after the cutting using the litter bag method.

\section{Production and planting of Brassica seedlings}

Broccoli, cauliflower and cabbage seedlings were produced in 128-cell styrofoam trays containing the commercial substrate Plantmax ${ }^{\circledR}$. In the beginning of July 2014 (thirty days after sowing into the trays), $10-15-\mathrm{cm}$ seedlings were transplanted to pits made on the residues of the cover crops. The planting was carried out with spacing of $0.80 \times 0.50 \mathrm{~m}$, totaling 24 plants per plot per treatment.

Evaluations of the Brassica crops were always done on eight plants in the two central rows for all treatments. The plants were sprinkler irrigated on daily basis, keeping the soil moisture close to the field capacity. The irrigation system consisted of a stationary conventional sprinkler system with $560 \mathrm{~L} \mathrm{~h}^{-1}$ sprinklers spaced 9 meters apart. The irrigation time was approximately 20 minutes. Weeds were controlled manually.

\section{Evaluations}

\section{Decomposition rate and residue half-life}

To evaluate the decomposition rate, the decomposition bag method was used as described by Santos and Whilford (1981). Into nylon litter bags (a mesh of $2 \mathrm{~mm}$, internal dimensions of $0.20 \times 0.20 \mathrm{~m}$ ) were placed $20 \mathrm{~g}$ of oven-dried at $65^{\circ} \mathrm{C}$ aerial parts of the cover plants.

Soon after the cutting of the cover crops, 24 bags were distributed on soil surface in each plot. Four bags per parcel were collected at each sampling, which occurred 15, 30, 60, 90, and 120 days after the distribution of the bags in the field (Torres et al., 2015, Assis et al., 2013). After collection of the samples, plant residues from each bag were manually cleaned, dried in a forced air circulation oven at $65^{\circ} \mathrm{C}$ until constant weight was reached, and finally weighed.

To describe the decomposition of plant residues, the exponential mathematical model described by Thomas and Asakawa (1993) was used: $X=X o e^{-k t}$, where: $X$ is the amount of dry biomass (DB) remaining after a period of time $\mathrm{t}$ (in days); Xo is the initial amount of DB or nutrient, and $\mathrm{k}$ is the decomposition constant of the residue.

Residue half-life ( $\mathrm{T}^{1 / 2}$ life), which expresses time required for half of the residues to decompose, was calculated using the $\mathrm{k}$ value (Paul and Clark, 1996). Mathematical equations that represent DB decomposition were elaborated using the software SigmaPlot version 10.

\section{Harvest of Brassica crops}

Broccoli and cauliflower harvest was performed when their inflorescences showed complete development, their flower buds were still attached, and their heads were compact and firm. The harvest started 90 days after planting and lasted for 30 days. During this period evaluations were performed every three days. For cabbage, the harvest began 100 days after planting, when the compactness (firmness) of the heads reached commercial acceptance, and lasted for 20 days.

\section{Agronomic performance}

After harvest, the plants were taken to the laboratory to evaluate agronomic traits: number of leaves $(\mathrm{NL})$, height $(\mathrm{H})$, fresh (FHW) and dry (DHW) head weight, and yield. 


\section{Statistical analysis}

\section{Normality and homogeneity}

The results underwent normality and homogeneity analyses through the Lilliefors, Cochran and Barttlet tests, respectively.

\section{Analysis of variance}

The results were submitted to analysis of variance with the statistical program SISVAR, The F-test was used to evaluate significance and the Tukey test to compare means $(\mathrm{p}<0.05)$. Mathematical equations were elaborated to describe the decomposition of plant residues using the software SigmaPlot, version 10 .

\section{Conclusion}

The highest dry biomass yield was observed in treatments with sunn hemp; Signal grass presented the highest decomposition constant and the shortest residue half-life in this study; Broccoli presented better agronomic performance when the crop was cultivated on residues containing sunn hemp; Fertilizer doses decisively influenced the yield of broccoli and cabbage, which was the highest in the treatment with $100 \%$ of mineral fertilizer.

\section{Acknowledgements}

The authors thank Instituto Federal do Triângulo Mineiro campus Uberaba for providing the facilities, and FAPEMIG and FUNDAÇÃO AGRISUS for granting undergraduate research scholarships to students and for funding the project.

\section{References}

Assis RL, Oliveira CAO, Perin A, Simon GA, Souza Junior BA (2013) Produção de biomassa, acúmulo de nitrogênio por plantas de cobertura e efeito na produtividade do milho safrinha. Enc Bio. 9: 1769-1775.

Bettiol JVT, Sá ME (2013) Plantas de cobertura, utilizando Urochloa ruziziensis solteira e em consórcio com leguminosas e seus efeitos sobre a produtividade de sementes do feijoeiro. Relatório Final do Processo 1056/12 da Fundação Agrisus, Ilha solteira, 55p.

Brito SS, Santos AC (2010) Decomposição e mineralização de nutrientes em função da aplicação de diferentes fontes de matéria orgânica. Enc Bio. 6: 1-8.

Carvalho C, Kist BB, Poll H (2013) Anuário brasileiro de hortaliças. Santa Cruz do Sul: Editora Gazeta Santa Cruz, 88p.

Carvalho AM, Souza LLP, Guimarães Júnior R, Alves PCAC, Vivaldi LJ (2011) Cover plants with potential use for crop- livestock integrated systems in the Cerrado region. Pesq Agr Br. 46: 1200-1205.

Castoldi R, Charlo HCO, Vargas PF, Braz LT (2009) Crescimento, acúmulo de nutrientes e produtividade da cultura da couve-flor. Hort Br. 27: 438-446.

Chioderoli CA, Mello LMM, Grigolli PJ, Furlani CEA, Silva JOR, Cesarin AL (2012) Atributos físicos do solo e produtividade de soja em sistema de consórcio milho e braquiária. Rev Br Eng Agr Amb. 16: 37-43.

Crusciol CAC, Soratto RP (2009) Nitrogen supply for cover crops and effects on peanut grown in succession under a no-till system. Agr Jour. 101: 40-46.

Diniz ER, Santos RHS, Urquiaga SS, Peternelli LA, Barrella TP, Freitas GB (2007) Green manure incorporation timing for organically grown broccoli. Pesq Agr Br. 42: 199-206.
Empresa Brasileira de Pesquisa Agropecuária - Embrapa. (2013) Sistema brasileiro de classificação de solos. $3^{\mathrm{a}}$ ed. Brasília, DF; 357 p.

Fabian AJ (2009) Plantas de cobertura: efeito nos atributos do solo e na produtividade de milho e soja em rotação. 83 f., (Tese de Doutorado) Doutorado em Agronomia Universidade Estadual Paulista, Jaboticabal-SP.

Fontanétti A, Carvalho GJ, Gomes LAA, Almeida K, Moraes SRG, Teixeira CM (2006) Adubação verde na produção orgânica de alface americana e repolho. Hort Br. 24: 146150.

Giacomini SJ, Aita C, Vendruscolo ERRO, Cubilla M, Nicoloso RS, Fries MR (2003) Matéria seca, relação C/N e acúmulo de nitrogênio, fósforo e potássio em misturas de plantas de cobertura do solo. Rev Br Ci So. 27: 325-334.

Kano C, Salata AC, Higuti ARO, Godoy AR, Cardoso AII, Evangelista RM (2010) Produção e qualidade de couve-flor cultivar Teresópolis Gigante em função de doses de nitrogênio. Hort Br. 28: 453-457.

Lêdo FJS, Souza JÁ, Silva MR (2000) Avaliação de cultivares e híbridos de repolho no Estado do Acre. Hort Br. 18: 138-140.

Leite LFC, Freitas RCA, Sagrilo E, Galvão SRS (2010) Decomposição e liberação de nutrientes de resíduos vegetais depositados sobre Latossolo Amarelo no Cerrado Maranhense. Rev Ci Agr. 41: 29-35.

Montenegro AAA, Abrantes JRCB, Lima JLMP, Singh VP, Santos TEM (2013) Inpact of mulching on soil and water dynamics under intermittents simulated rainfall. Cat. 109: 139-149.

Morais Junior PO, Cardoso AF, Leão EF, Peixoto N (2012) Desempenho de cultivares de couve-flor de verão em Ipameri. Ci Rur. 42: 1923-1928.

Oliveira FL, Ribas RGT, Junqueira RM, Padovam MP, Guerra JGM, Almeida DL, Ribeiro RLD (2005) Desempenho do consórcio entre repolho e rabanete com pré-cultivo de crotalária, sob manejo orgânico. Hort Br. 23: $184-188$.

Oliveira FL, Guerra JGM, Junqueira RM, Silva EE, Oliveira FF, Espindola JAA, Almeida DL, Ribeiro RLD, Urquiaga $S$ (2006). Crescimento e produtividade do inhame cultivado entre faixas de guandu em sistema orgânico. Hort Br. 24: 53-58.

Paul EA, Clark FE (1996) Dynamics of residue decomposition and soil organic matter turnover. In: Paul EA, Clark FE eds. Soil microbiology and biochemistry. $2^{\circ}$ ed. San Diego, Academic, p.158-179.

Perin A, Cruvinel DA, Ferreira HS, Melo GB, Lima LE, Andrade JWS (2015) Decomposição da palhada e produção do repolho em sistema de plantio direto. Gl Sci Tech. 153159.

Santos PF, Whilford WG (1981) The effects of microarthropods on litter decomposition in a chihuazhuan ecosystem. Ecol. 62: 654 - 669.

Santos ES, Montenegro AAA, Pedros EMR, Silva EFF (2016) Crescimento e produção de repolho sob diferentes adubações na presença e ausência de cobertura morta em agricultura familiar. Irr. 21: 74-89.

Soil Fertility Commission of the State of Minas Gerais (1999) Recomendações para o uso de corretivos e fertilizantes em Minas Gerais: $5^{\text {a }}$ aproximação. Viçosa: CFSEMG, 359 p.

Souza ER, Montenegro AAA, Montenegro SMG, Matos JA (2011) Temporal stability of soil moisture in irrigated carrot crops in Northeast Brazil. Agric Wat Man. 99: 2632.

Thomas RJ, Asakawa NM (1993) Decomposition of leaf litter from tropical forage grasses and legumes. So Biol Bioch. 25: 1351-1361. 
Torres JLR, Pereira MG, Andrioli I, Polidoro JC, Fabian AJ (2005) Decomposição e liberação de nitrogênio de resíduos culturais de plantas de cobertura em um solo de Cerrado. Rev Br Ci Sol. 29: 609-618.

Torres JLR, Pereira MG, Fabian AJ (2008) Produção de fitomassa por plantas de cobertura e mineralização de seus resíduos em plantio direto. Pesq Agr Br. 43: 421-428.

Torres JLR, Santana MJ, Pizolato Neto A, Pereira MG, Vieira DMS (2013) Produtividade de feijão sobre lâminas de irrigação e coberturas de solo. Biosc Jour. 29: 833-841.

Torres JLR, Araujo AS, Barreto AC, Silva Neto OF, Silva VR, Vieira DMS (2015) Desenvolvimento e produtividade da couve-flor e repolho influenciados por tipos de cobertura do solo. Hort Br. 33: 510-514.
Torres JLR, Pereira MG, Loss A (2016) Produção, decomposição e ciclagem de nutrientes das coberturas de solo utilizadas no sistema de semeadura direta no cerrado. In: Amaral Sobrinho NMB, Chagas CI, Zonta E (Org.) Impactos Ambientais Provenientes da Produção Agrícola: Experiências Argentinas e Brasileiras. 1ªed. São Paulo: Rio de Janeiro: Livre Expressão, 1: 305-338.

Uberaba. [Brasil] Prefeitura Municipal. Uberaba em dados. Edição 2009 [acesso em 21 nov 2011]. Disponível em: http://www.uberaba.mg.gov.br/portal/acervo/desenvolvime nto/arquivos/uberaba_em_dados/Edicao_2009/Capitulo01. pdf.

Vargas TO, Diniz ER, Santos RHS, Lima CTA, Urquiaga S, Cecon PR (2011) Influência da biomassa de leguminosas sobre a produção de repolho em dois cultivos consecutivos. Horti Br. 29: 562-568 